\title{
Doporučené postupy léčby arteriální hypertenze ve světle pandemie covidu-19; existuje důvod ke změnám?
}

Na kongrese 16. Interní medicína pro praxi vysílaném on-line z Olomouce 30. dubna 2021 zazněla přednáška Doporučené postupy léčby arteriální hypertenze ve světle pandemie covidu-19; existuje důvod ke změnám? věnovaná platným doporučením pro diagnostiku a léčbu arteriální hypertenze. MUDr. Pavel Rutar ve své přednášce vycházel zejména z doporučení vydaných Evropskou kardiologickou společností (ESC) a Evropskou společností pro arteriální hypertenzi (EHC) v roce 2018. V první části přednášky se věnuje některým důležitým faktům obsaženým v těchto doporučených postupech, zejména s ohledem na jejich dopad do každodenní klinické praxe. Druhá část jeho přednášky pak byla věnována tématu mnohokrát skloňovanému v posledním roce, tedy prípadnému vztahu mezi onemocněním covid-19 a antihypertenzní terapií.

\section{EHC/ESC doporučení pro management arteriální hypertenze $\mathrm{z}$ roku 2018}

I přes to, že v roce 2020 byla vydána nová mezinárodní doporučení pro léčbu arteriální hypertenze, nepřinesla do naší praxe zásadní novinky, jako se tomu stalo v roce 2018 při publikaci klinických doporučených postupů EHC/ESC, které ve srovnání s verzí z roku 2013 vedly k zavedení několika podstatných změn. V doporučeních EHC/ESC z roku 2018 je významnější prostor věnován diagnostice arteriální hypertenze mimo zázemí ambulance, tedy v domácím prostředí, větší dưraz je kladen na dosahování cílových hodnot krevního tlaku (TK), přičemž je zde zřetelně vidět obecný posun k proaktivnějšímu způsobu léčby, který neopomijí ani skupinu pacientů ve věku nad 65 let. Doporučení z roku 2018 rovněž významně řeší i otázku adherence pacienta k terapii, tedy neříkají již jen jakými léky a jakými kombinacemi léků máme léčit, ale i jakou formu léků máme zvolit.

\section{Monitorace arteriálního krevního tlaku mimo ambulanci}

Domácí monitorace arteriálního krevního tlaku je významnou metodou v diagnostice i následném sledování úspěchu léčby arteriální hypertenze. Monitorace TK v domácím prostředí je indikovaná nejen u pacientů, u kterých se po záchytu TK v ambulanci nad 140/90 mmHg snažíme potvrdit či vyvrátit diagnózu arteriální hypertenze, nýbrž i u pacientů, kteří při ambulantní kontrole vykazují hodnoty krevního tlaku v pásmu vyššího normálního tlaku, tedy hodnoty 130-139/8589 mmHg. Až $15 \%$ těchto "normotenzních" pacientů jsou totiž ve skutečnosti nerozpoznaní hypertonici, a jedině domácí monitorace 24hodinovým TK Holterem či opakovaná domácí měření (2 až 3 měrení TK $2 \times$ denně po pěti minutách klidu po dobu alespoň 3, lépe 6 až 7 dnů) nám dokáží tuto diagnózu správně stanovit. Za normotenzi při domácí automonitoraci krevního tlaku považujeme hodnoty TK do 135/85 mmHg, u TK Holter monitorace je pak hranice normy pro dvacetičtyřhodinový průměr do 130/80, pro denní průměr do 135/85 mmHg a pro noční průměr do 120/70 mmHg

\section{Zahájení farmakoterapie a cíle léčby arteriální hypertenze}

Mezní hodnoty indikující zahájení léčby arteriální hypertenze jsou pro ambulantní měření u pacientů do 80 let 140/90 mmHg a u pacientů nad 80 let 160/90 mmHg. Všem hypertonikưm pochopitelně doporučujeme úpravu režimu a dodržování zásad zdravého životního stylu s přiměřenou dietou a pravidelnou aerobní aktivitou. Se zahájením farmakoterapie u hypertoniků můžeme vyčkat, jedná-li se o jinak zdravé jedince s arteriální hypertenzí l. stupně, kdy farmakoterapii zahajujeme po 3-6 měsících neúspěšných pokusů o režimová opatření. Naopak v prípadě stanovení arteriální hypertenze II. a vyššího stupně (hypertonici s hodnotami TK >160/100 mmHg) zahajujeme farmakotarepii arteriální hypertenze bezodkladně u všech pacientů, bez ohledu na jejich komorbidity. U rizikových pacientů (hypertonici s kardiovaskulárním onemocněním či orgánovým poškozením na podkladě arteriální hypertenze) je zahájení farmakoterapie arteriální hypertenze indikováno bez ohledu na její tíži, tedy již od I. stupně. U pacientů s významnou kardiovaskulární problematikou, zejména ischemickou chorobou srdeční (ICHS), pak zvažujeme zahájení či augmentaci stávající léčby již při hodnotách TK v pásmu vyššího normálního tlaku.

Při zahájení léčby arteriální hypertenze provádíme časnou korekci TK na hodnoty kolem 140/90 mmHg a v následujících třech měsících pakza monitorace klinického stavu pacienta a sledování tolerance léčby titrujeme medikaci k dosažení cílových hodnot krevního tlaku, tedy hodnot do 130/70-79 mmHg u pacientů do 65 let věku a 130-139/70-79 mmHg ve skupině pacientů nad 65 let (pokud takovouto korekci tolerují). Při titraci medikace je vždy nutné zvažovat individualitu pacienta a v řadě prípadů může být pomalejší korekce prínosnější než přehnaně útočná a nepríijemnými symptomy provázená rychlá korekce arteriálního krevního tlaku. Za každou cenu bychom se měli snažit vyhnout nežádoucí „hyper- 


\section{ZAZNĚLO NA 16. KONFERENCI INTERNÍ MEDICÍNA PRO PRAXI}

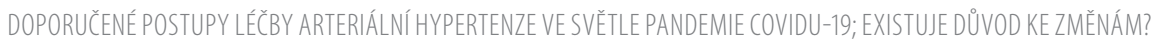

kompenzaci", tedy navození hodnot TK < 120/70 mmHg. Vyšší opatrnosti při titraci léčby je nutné dbát v populaci křehkých geriatrických pacientů a rovněž i v populaci pacientů s chronickou renální insuficiencí, u nichž je primárním cílem dosažení hodnoty TK < 140/70-79 mmHg a další titrace na nižší hodnoty krevního tlaku je indikovaná pouze u těch pacientů, kterým naší léčbou nenavodíme zhoršení jejich renálních funkcí.

\section{Léčba arteriální hypertenze aneb když jedna je lepší než dva nebo dokonce tři}

V léčbě arteriální hypertenze využíváme pět základních skupin léků ACE inhibitory (ACEI), sartany neboli AT1 blokátory (AT1B), blokátory kalciových kanálů (BKK), betablokátory (BB) a diuretika. V rámci farmakoterapie arteriální hypertenze mezi sebou tyto jednotlivé skupiny léků kombinujeme, přičemž volba konkrétních kombinací je dána zejména individualitou pacienta, a tedy jeho komorbiditami. Dle současných doporučení zahajujeme terapii arteriální hypertenze dvoukombinací farmak (vyjma situací léčby křehkých geriatrických pacientů a pacientů s hodnotami TK $\leq 150 \mathrm{mmHg}$ ). Při nedostatečné kompenzaci krevního tlaku i po navýšení dávek pak léčbu rozšiřujeme na trojkombinační či čtyřkombinační. Novinkou, která se objevila v doporučených postupech z roku 2018, je důraz na volbu správné formy antihypertenziv. Tím zásadním pro efekt farmakoterapie je totiž adherence pacienta k léčbě. Jen léky skutečně užívané mohou navodit klinický efekt. Spolupráci pacienta je vhodné zvyšovat opakovanou edukací a vysvětlováním prospěšnosti léčby, nicméně ještě významnějším hráčem na poli adherence k farmakoterapii je samotný rozpis léčby, respektive jeho jednoduchost. Z klinických studií jednoznačně vyplývá, že jednoduché dávkovací schéma, ideálně dávkování jednou denně, př̆i co nejmenším počtu tablet, nejlépe tedy s jednou jedinou tabletou, dosahuje v praxi nejvyšší adherence. A právě toto je důvod, proč doporučení pro léčbu arteriální hypertenze z roku 2018 i z roku 2020 jednoznačně zdůrazňuji preferenční využivání preparátů s fixní kombinací léčiv, a proč by tedy i pacient užívající trojkombinaci antihypertenziv měl užívat svou léčbu v jedné tabletě v jedné denní dávce.

\section{Fixní kombinace léčiv}

Preparáty s fixní kombinací léčiv musí stejně jako ostatní léčiva prokazovat kromě bezpečnosti i svou dostatečnou účinnost. Protože cílem těchto preparátů je zjednodušit schéma léčby, a ve většině prípadů tedy dávkovat jednou denně, je nezbytné, aby v těchto preparátech byla obsažena farmaka s dlouhodobým, ideálně dvacetičtyřhodinovým klinickým účinkem. Tuto vlastnost splňuji z běžně uživaných antihypertenziv dostupných ve fixních kombinacích zejména perindopril, amlodipin, indapamid a telmisartan. Jedním z ukazatelů klinického denního pokrytí účinku farmaka je trough to peak ratio (T/P ratio), které nám říká po jakou část dne přetrvává klinický účinek podané molekuly. U výše uvedených molekul se hodnoty T/P ratio pohybují kolem 90 až $100 \%$ Z betablokátorů má pak nejvyšší hodnotu T/P ratio, a tedy nejdelší klinickou účinnost, nebivolol. Hodnoty T/P ratio ostatních molekul běžně užívaných v léčbě arteriální hypertenze jsou povětšinou významně nižší, a svědčí tedy o kratším klinickém efektu těchto farmak (např. T/P ratio ramiprilu se pohybuje někde kolem 50-60\%, hydrochlorothiazidu dokonce kolem pouhých 33\%).

\section{ACEl vs. sartany}

Ačkoliv doporučené postupy EHC/ECS pro léčbu arteriální hypertenze z roku 2018 řadí ACEl na téměř totožné místo se sartany, je nutné si položit otázku, zda jsou tyto skupiny skutečně rovnocenné i ve všech dalších ohledech. Ačkoliv občas slýcháme, že "ATB1 jsou ACEl bez kašle", je nutné zachovat si nadhled a nepodléhat takovýmto nepřesným zjednodušením. ACEl a sartany mají rozdílný způsob působení ve smyslu zásahu do renin-angiotenzin-aldosteronového systému (RAAS), a tedy již z tohoto pohledu nelze očekávat, že budou mít stejné klinické účinky a stejné klinické dopady. ACEl jsou, ve srovnání s AT1B jednoznačně prínosnější co do redukce mortality pacientů s arteriální hypertenzí, cukrovkou či ICHS a jsou také efektivnější u pacientů s chronickým srdečním selháním.

\section{Postavení betablokátorů v léčbě arteriální hypertenze}

Betablokátory jsou skupinou patřící mezi základní antihypertenziva, přičemž jsou jako první volba v léčbě arteriální hypertenze indikovány u pacientů, u kterých existuje k užívání betablokátoru kromě arteriální hypertenze i jiná indikace (typicky ICHS, fibrilaci síní nebo chronické srdeční selhání). Betablokátory jsou v léčbě arteriální hypertenze vhodné rovněž u prekoncepčních či gravidních, dále u pacientů s hyperkinetickou cirkulací či palpitacemi nebo u pacientek trpících vegetativními doprovody menopauzy. Při volbě konkrétní molekuly betablokátoru se pak primárně řídíme schválenými indikacemi jednotlivých molekul (ne každý betablokátor má indikaci např. k léčbě fibrilace síní nebo chronického srdečního selhání), a dále zohledňujeme jejich selektivitu. V prípadě, že nasazujeme betablokátor čistě z indikace arteriální hypertenze, je velmi výhodnou molekulou nebivolol. Nebivolol je ultraselektivní betablokátor 3. generace, nejselektivnější ze všech molekul betablokátorů. Jeho vysoká selektivita zaručuje výbornou toleranci léčby a výskyt minima nežádoucích účinků a dovoluje jeho využití např. i u pacientů s chronickou obstrukční plicní nemocí. Nebivolol je z pohledu metabolismu glukózy a lipidového spektra metabolicky neutrální a svým vlivem na produkci NO v cévách navozuje vazodilataci, príznivě ovlivňuje erekci a príznivě zasahuje i do procesu aterogeneze.

\section{Indapamid vs. hydrochlorothiazid}

Nejčastěji užívanými diuretiky z indikace arteriální hypertenze jsou indapamid a hydrochlorothiazid (HCT). Ač se jedná o léky ze stejné lékové skupiny, není mezi nimi rovnítko a jejich výsledný klinický efekt je rovněž značně rozdílný. Indapamid je metabolicky neutrální molekula, která kromě diuretického efektu navozuje i vazodilataci ovlivněním influxu kalcia do myocytů cévní stěny, a navíc snižuje senzitivitu katecholaminergních receptorů cév. Indapamid má pak i raadu dalších výhodných vlastností, které u HCT nenajdeme, např. schopnost navození redukce velikosti levé komory srdeční při dlouhodobé terapii nebo schopnost redukce albuminurie u diabetiků. Indapamid ve srovnání s HCT navíc navozuje významnější pokles krevního tlaku a má výhodnější a násobně delší klinický účinek (24 hodin vs. 12 hodin u HCT). Výskyt hypokalemie, jakožto nežádoucího účinku obou molekul, je u indapamidu i HCT srovnatelný. 


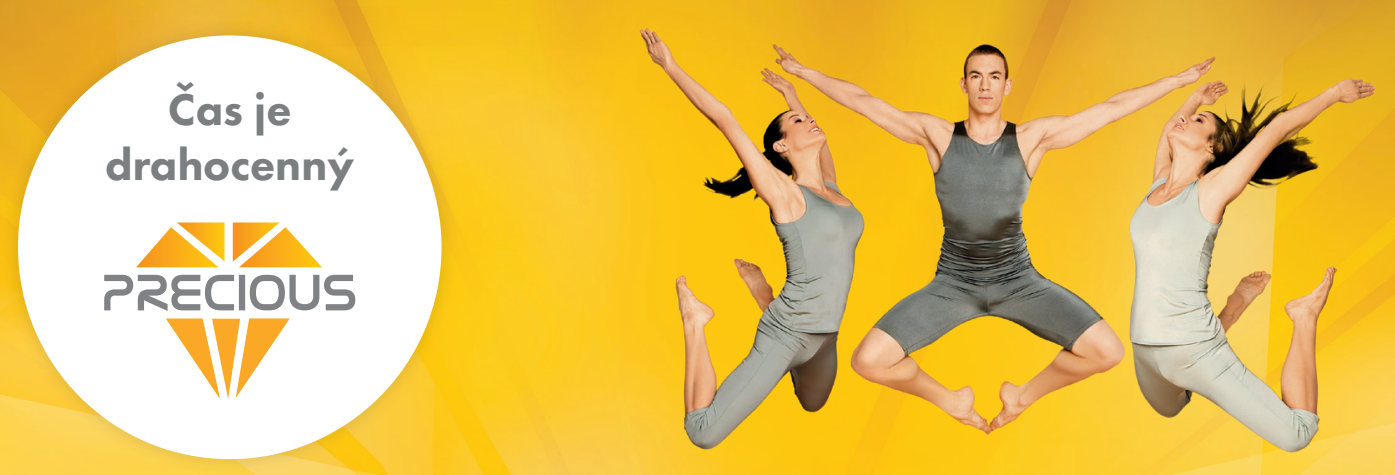

Čas a zdraví jsou dvě drahocenná aktiva, která neuznáváme a neoceníme, dokud nebudou vyčerpána.

Denis Waitley

\section{Jednodušší léčba pro Vaše pacienty}

$$
\begin{aligned}
& \text { měsíc po změně léčby } \\
& \mathbf{- 1 4 . 4} / \mathbf{9 . 0} \mathrm{mmHg} \\
& \text { pokles TK }
\end{aligned}
$$

TK - krevní tlak

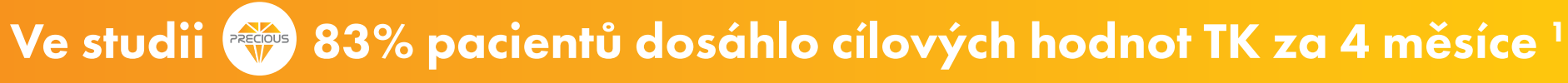

TONANDA

Základni informace pro predpis léciveho pr̆ipravku:

(piipraveno podle schváleného Souhnu údajü opīiparku)

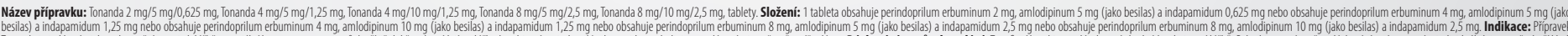

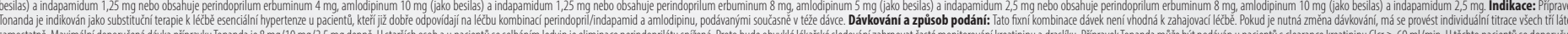

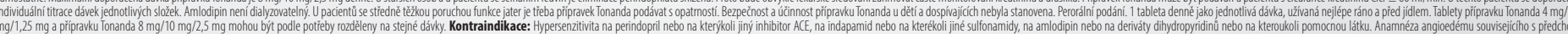

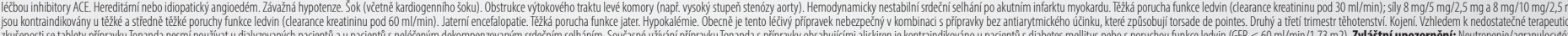

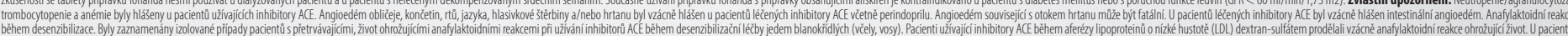

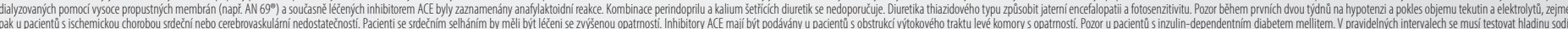

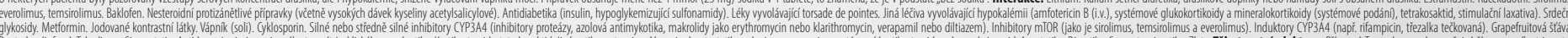

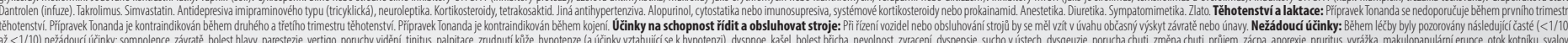

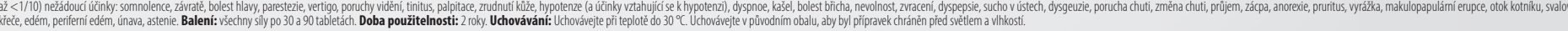
Dive než prĭpravek préedepišste, seznna 


\section{ZAZNĚLO NA 16. KONFERENCI INTERNÍ MEDICÍNA PRO PRAXI}

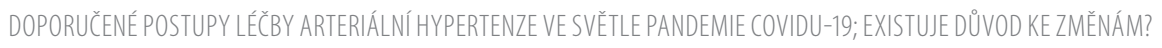

\section{Antihypertenziva a covid-19}

$\checkmark$ důsledku propuknutí pandemie covidu-19 a vzhledem k tomu, že arteriální hypertenze je jedním z onemocnění, které zvyšuje riziko těžkého průběhu covidu-19, byla od počátku roku 2020 všechna antihypertenziva pod drobnohledem, přičemž zrak vědců se upíral zejména ke skupině ACEl a AT1B, nebot u těchto molekul je předpoklad indukce angiotenzin konvertujícího enzymu typu 2 (ACE2), který slouží jako receptor pro SARSCoV-2 a vyskytuje se na buněčných membránách pneumocytů II, endotelu a na buněčných membránách řady dalších buněk. Aktivace ACE2 vede k hned několika nežádoucím dějưm - k rozvoji proinflamatorních pochodů, vazokonstrikci, zhoršení oxidativních funkcí a zvýšení rizika trombózy. $\checkmark$ současnosti již máme k dispozici výsledky řady klinických studií, které nám poskytují odpovědi na otázky vztahu antihypertenziv a covidu-19. Reynoldyho studie z června 2020 z New Yorku zkoumala na vzorku 12594 pacientů testovaných na SARS-CoV-2 souvislost mezi rizikem akvírování tohoto viru a užíváním antihypertenzní medikace a dále vztah mezi závažností průběhu covidu-19 u pacientů užívajících antihypertenziva. Tato studie neprokázala souvislost mezi pozitivitou testu a jakoukoliv antihypertenzní medikací, stejně jako neprokázala asociaci mezi antihypertenzní medikací a horším průběhem covidu-19. Ani retrospektivní populační studie ze sedmi madridských nemocnic publikovaná De Abajem v Lancetu v květnu 2020, která zkoumala vzorek 1139 pacientů, k nimž byl vybrán desetkrát větší kontrolní vzorek pacientů, neprokázala, že by terapie ACEI či AT1B zvyšovala riziko hospitalizace pacientů s covidem-19. Ǩada dalších menších studií zaměřujících se na vliv ACEl a AT1B na průběh covidu-19 pak souhlasně došla k obdobným závěrưm, tedy nebylo prokázáno, že vysazení ACEl či AT1B u pacientů s covidem-19 zlepší jejich prognózu. Naopak, neuváženým vysazením této medikace mưžeme zvýšit kardiovaskulární mortalitu našich pacientů v důsledku dekompenzace jejich chronického kardiovaskulárního onemocnění.

\section{Závěr}

V léčbě arteriální hypertenze vycházíme zejména z kombinační terapie za současné preference využivání molekul s dlouhodobým klinickým účinkem. S ohledem na zvýšení adherence pacienta k terapii se snažíme maximálně využívat fixních kombinací léčiv. Asi nejtypičtějšími molekulami ze skupiny antihypertenziv splňujícími obě tyto podmínky jsou perindopril, amlodipin a indapamid. Při volbě antihypertenziv vycházíme ze znalostí základních skupin antihypertenziv, přičemž je nutné brát v potaz, že mezi klinickými účinky ACEl a sartanů není rovnítko, a AT1B bychom tedy měli využívat až v prípadě, že pacient netoleruje výhodnější molekuly ze skupiny ACEl. Betablokátory jsou stále jednou ze základních skupin antihypertenziv, které využíváme v terapii hypertoniků, zejména pokud pro jejich užití nacházíme i další indikaci (ICHS, fibrilace síní, chronické srdeční selhání). Betablokátory jsou výhodné i u prekoncepčních či gravidních a u pacientů se známkami hyperkinetické cirkulace či palpitacemi. Z betablokátorů jednoznačně preferujeme moderní selektivní molekuly, přičemž nejselektivnějším betablokátorem na trhu je nebivolol, který se vyznačuje ojedinělým pưsobením cestou NO, čímž mimo jiné napríklad př́znivě zasahuje i do procesu aterogeneze. Současná antihypertenziva jsou i v době pandemie covidu-19 bezpečná. Neexistují reálné dưvody k paušálnímu vysazování či změnám antihypertenzní medikace z důvodu covidu-19. Úprava aktuální antihypertenzní terapie je u pacientů s probíhajícím onemocněním covid-19 na místě jen v prípadě, že u nich v důsledku onemocnění dojde k rozvoji systémové hypotenze, renální insuficience apod. Neuvážené vysazení ACEI či AT1B nebo i jiných antihypertenziv z indikace covidu-19 mưže ve svém důsledku pacienta poškodit rozvojem dekompenzace jeho chronického kardiovaskulárního onemocnění.

MUDr. Pavel Rutar Interní oddělení Nemocnice Na Homolce 